Check for updates

Montreal

Cite this as: BMJ 2021;372:n428 http://dx.doi.org/10.1136/bmj.n428 Published: 11 February 2021

\title{
Covid-19: WHO says laboratory escape theory is "extremely unlikely" after mission to China
}

\section{Owen Dyer}

A team of scientists sent to Wuhan, China, by the World Health Organization to investigate the origins of the covid-19 pandemic has effectively ruled out the hypothesis of a viral escape from the nearby Wuhan Institute of Virology.

It was "extremely unlikely" that the laboratory's work was behind the outbreak that struck the city at the end of 2019, said Peter Ben Embarek, a Danish food safety and animal disease specialist who chaired the investigation team. "It isn't a hypothesis we suggest implies further study."

"All the work that has been done on the virus and trying to identify its origin continues to point toward a natural reservoir," he added. "It's very unlikely that anything could escape from that place,” said Embarek of the virology laboratory, which his team briefly visited.

"Accidents do happen," he conceded, but he said that the viruses kept in the Wuhan laboratory, and other similar laboratories elsewhere, were genetically too different from the SARS-CoV-2 virus to be its likely progenitors. "There had been no publication or research of this virus or one close to this virus, anywhere in the world," he said.

The laboratory escape theory was seized on early in the pandemic by the then US president Donald Trump and his supporters, as they sought to deflect blame for a sluggish US response. But few experts have backed the claims.

The Trump administration, which had initially praised China's response, later criticised WHO for being allegedly too solicitous of China's concerns. Trump declared in July 2020 that the US would quit the WHO, a decision reversed in the first hours of the Biden administration.

China, meanwhile, positioned itself as a WHO defender but simultaneously resisted the agency's efforts to send a team to Wuhan to investigate the disease's origins. WHO negotiated for months to obtain access, and China imposed a further unexplained two week delay last month, after some of the investigators had already begun their journey.

The 12 day visit, during which investigators were closely shepherded by Chinese officials, may not placate critics of WHO. The initial findings will be seen as a public relations coup for the Chinese government, whose officials have at times sought to suggest that the virus first emerged in a completely different country, at different times positing Italy, India, and the US as likely candidates.

The WHO team lent no support to those claims but did open the door to another theory popular in China: that frozen foods may have helped spread the virus around the world.

Liang Wannian, head of China's expert panel on covid-19, who spoke before Embarek, said that coronaviruses found in bats-and in pangolins, another early suspect-were "insufficiently similar to be identified as the progenitor of SARS-CoV-2."

Some unknown intermediate species probably facilitated the leap into humans, he said, pointing to feline species and minks, which have been seen with symptomatic covid-19.

"Connected to this hypothesis is the theory of transmission by cold chain products,” said Embarek. He called for further investigation of the "possible role of cold chain, frozen products in the introduction of the virus over a distance."

The US government said it would not accept WHO's findings without verifying them independently. "We will work with our partners, and also draw on information collected and analysed by our own intelligence community," said a Department of State spokesman.

"Biden has to look tough on China," the WHO team's only UK member, the zoologist Peter Daszak, tweeted in response. "Please don't rely too much on US intel: increasingly disengaged under Trump and frankly wrong on many aspects.” 